\title{
EAST AFRICAN ODONATA, COLLECTED BY DOCTOR W. L. ABBOTT.
}

\author{
By Philip P. Calvert.
}

ThE Odonata collected in Zanzibar and the Kilimanjaro region in 1889-90 by Dr. W. L. Abbott were sent by him to the United States National Museum at Washington in two lots. Thanks to the kindness of the authorities of the Museum, I have had the opportunity of studying them, with the results set forth in the following pages. The total number of specimens is sixty-four, representing thirteen species. Of these, four species are here described as new, viz: Orthetrum truncatum, O. abbotti, Aeschna rileyi, and Disparoneura abbotti. Three other species, Trithemis furrugaria, Rambur, Orthetrum brachiale, Beauvois, and Anax rutherfordi, McLachlan, have hitherto been known only by brief descriptions or by but one sex; the present opportunity has been seized to render our knowledge of them more complete.

PANTALA FLAVESCENS, Fabricius.

Libellula flavescens, FABricius, Ent. Syst. Suppl., p. 285, 1798.

Pantala flavescens, Hagen, Syn. Neur. N. Amer., p. 142, 1861; Stett. Ent. Zeit., XXVIII, p. 215, 1867; Proc. Bost. Soc. Nat. Hist., XVIII, p. 63, 1875.-KIrBy, Cat. Odon., p. 1, 1890.

Libellula viridula, Brauvors, Ins. Afr. Amer., p. 69, Névr., pl. III, fig. 4, 1805-1821.Rambur, Nèvropt., p. 38, 1842.

Libellula analis et terminalis, Burmerster, Handb. Ent., II, p. 852, 1839.

Libellula Sparshallii, Curtis, Guide, p. 162.-Selys, Monog. Lib. Eur., p. 36, 1840; Revue Odon. Eur., p. 322, 1850.

Locality.-One female in the National Museum collection, from Kilimanjaro. This species, as is well known, is distributed all over the world, except Europe.

TRAMEA LIMBATA, Desjardins.

Libellula limbata, DesJardins, Rapport Soc. Maurice, I (1832); Bull. Soc. Ent. France, IV, p. 4, 1835.

Tramea limbata, Kinby, Trans. Zool. Soc. Lond., XII, p. 318, 1889; Cat. Odon., p. $4,1890$.

Libellula mauriciana, Rambur, Nérr., p. 34, 1842.

One female in the National Museum collection, obtained at the Seychelles by Dr. W. L. Abbott, belongs, I believe, to this species. It differs 
from Rambur's description only in having the posterior angle of the lateral lobes of the labium luteous, not black, and the articulations of the abdomen are blackish, especially at the sides.

Additional details: Appendages longer than the last two, but not as long as the last three, abdominal segments.

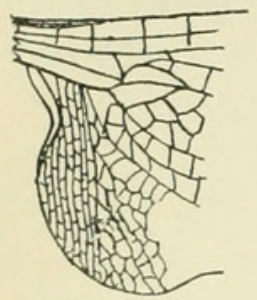

Fig. 1.

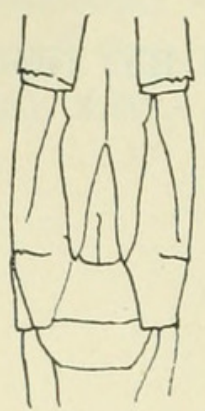

Fig. 2.

TRAMEA LIMBATA, Female.

(1) Base of right hind wing: (2) Ventral sur face of last two abdominal segments.

Basal spot of hind wings deeply cleft exteriorly at the basilar space, reaching outward in the subcostal space to the first antecubital; in the median space not as far as the triangle except by a slender limb along the postcostal vein to the posterior angle; no clear space within the spot along the anal margin, but just beyond the apex of the membranule is a paler area, where the cells, like those below the postcostal vein, are clearer in the center. Front wings with 11-12 antecubitals, 9-10 postcubitals, triangle with one eross vein. Hind wings with 7 antecubitals, 11-12 postcubitals. Pterostigma luteous, longer on front than on hind wings.

Measurements.-Length, $46 \mathrm{~mm}$. Abdomen (including appendages), 31. Front wing, 43. Hind wing, 41. Pterostigma, 3 (front), 2 (hind). Appendages, 3.6.

\section{SCHIZONYX LUCTIFERA, Selys.}

Zygonyx ? luctifera, Selys, Ann. Soc. Ent. Belg., XII, p. 96, 1869; Ann. Mag. Nat. Hist. (4), III, p. $273,1869$.

Schizonyx Tuctifera, KARsch, Berl. Ent. Zeit., XXXIII, p. 281, 1890.-Selys, Ann. Soc. Ent. Belg., XXXV, p. cexxvi, 1891.

Schizopyga luctifera, KinBy, Cat. Odon., p. 184, 1890.

Male.-Vertex truncate, dark metallic blue. Frons with a median groove superiorly, dark metallic blue, a yellow spot on each side inferiorly. Nasus black in the middle, yellow on each side. Rhinarium and lips black; occiput brown.

Prothorax blackish; posterior lobe very small; its hind margin entire, rounded.

Thorax dark metallic blue; a humeral stripe and five or six spots on the sides, yellow.

Feet blackish; femora somewhat reddish. Hairs of the feet short, 14-15 pairs on hind tibiæ.

Abdomen black, rather slender, very little swollen at the base, tapering gradually to apex; 2 and 3 each with a supplementary carina, that of 3 forming an obtuse angle, directed forward, on the dorsum of the segment; 4 with a slight indication of a supplementary carina.

Superior appendages not as long as the last two segments, black; viewed from above, straight, slightly thickened on the inner side before the apex, which is moderately acute; viewed from the side, each is directed downward, thickened inferiorly in the apical half with 3-4 
denticles on the basal side of the thickening, apex acute. Inferior appendage about one-eighth shorter than the superiors, dark brown; viewed from below, triangular; apex slender, about one-tenth as wide as base, moderately acute, extreme tip upcurved.

Genitalia of 2 not prominent. Anterior lamina rather flat, a small tubercle and a depression on each side; apex rounded, entire. Hamule projecting farthest, its apex bifid, so that the anterior (internal) branch forms a distinet, rounded, and somewhat slender hook; posterior branch not devesoped. Genital lobe rather narrow, not projecting as far as lamina or hamule.

Wings hyaline, reticulation blackish. Pterostigma dark brown, trapezoidal, its external side forming a more acute angle with the costa than the internal. Membranule pale-brownish. Sectors of the arculus distinctly stalked; no hypertrigonals; one median cross vein ${ }^{1}$ placed distinctly nearer the base than the first antecubital; discoidal triangles free (with one cross vein in the right front wing of one male), that of the front wing placed a short distance (1.5 mm.) beyond the apex of that of the hind wing; nodal sector distinctly waved beyond the middle. Front wings with 10-11 antecubitals, the last one not continuous; 9-10 posteubitals; internal triangle of one or two cells, hardly distinct from adjacent cells; two or three posttriangular cells; then two rows. Hind wings with 6-7 antecubitals, 11-12 postcubitals, no internal triangle, inner side of discoidal triangle slightly nearer the base than the prolongation of the arculus; two or three rows of posttriangular cells; sectors of the triangle united at their origin.

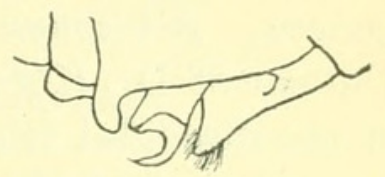

Fig. 3.

SCHIZONYX LUCTIFERA, Male.

Side view of genitalia of second abdominal segment.

Measurements.-Length of male, $45 \mathrm{~mm}$. Abdomen (including appendages), 33. Front wing, 38. Hind wing, 37. Distance of nodus from base on front wings, 20; on hind wings, 16. Pterostigma, 2. Superior appendages, 2.

Locality.-Two males in the National Museum collection, obtained at the Seychelles by Dr. W. L. Abbott.

The female is unknown to me.

The generic characters of Schizonyx, as drawn up by Dr. Karsch 2 and Baron de Selys, ${ }^{3}$ are as follows: Eyes with a small projection on their hind margin as in the Cordulina; cardinal cell triangular [=discoidal triangle]; in the front wings placed as in the Libellulina, with the acute angle directed backward, free; internal triangle of front wings two [or one] celled; two rows of posttriangular

"One cross vein in the space called "median" by Baron de Selys in the Monog. Gomph., pl. 22, but "sous-median" in his paper in Vol. XXXV, Ann. Soc. Ent. Belg.

${ }^{2}$ Berl. Ent. Zeit., XXXIII, p. 281, 1890.

${ }^{3}$ Ann. Soe. Ent. Belg., XXXV, p. cexxvi, 1891. 
cells in the front wings; anal angle of hind wings of male rounded, no internal triangle on the hind wings; tooth on tarsal nails shorter than the apex of the nail itself; nodus [slightly] nearer the apex than the base [of the front wings]; front wings with 10 [-11] antecubitals, the last one not continuous; only one median cross vein in all four wings.

With these characters the present specimens agree, the slight modifications which I have inclosed in brackets being of little importance.

In Dr. Karsch's "Beiträge zur Kenntniss der Arten und Gattungen der Libellulinen," he has placed the genera Schizony $x$, Karsch, and its ally Zygonyx, Selys, in that "Abtheilung" (of Brauer's fourth group) characterized by having the sectors of arculus separated at their origin or arising from a very short stalk. It would appear, however, that at that writing at least, Dr. Karsch had not seen any specimens of Zygonyx or Schizonyx, ${ }^{2}$ nor did any then published description mention this detail of venation. Baron de Selys ${ }^{3}$ says of Zygonyx, "secteurs de l'arculus soudés a la base en une seule tige," and mentions no difference in this respect for Schizonyx. The specimens of S. luctifera above described have the sectors of the arculus as distinctly stalked at their origin as in Orthetrum, Macrothemis, or other undoubtedly long-stalked genera. Schizonyx would thus fall within the group Scapanea to Untamo of Dr. Karsch's arrangement. On the other hand, the position of the discoidal triangle of the front wings, in being situated a little beyond that of the hind wings, as well as the trapezoidal form of the pterostigma, indicates some affinities with the group of Tramea, Hagen. Of the nine genera recognized by Mr. Kirby and Dr. Karsch as belonging to this group, the tropical American Miathyria, Kirby, most approaches Schizonyx, but differs from the latter in having no small prominence on the hind margin of the eyes, nodal sector not waved beyond the middle; front wings with $7-9$ antecubitals, 5-8 postcubitals; hind wings with 4-5 antecubitals, 6-9 postcubitals, and proportionately wider at base than in Schizonyx.

\section{PALPOPLEURA VESTITA, Rambur.}

Palpopleura vestita, Rambur, Névropt., p. 132, pl. 3, fig. 2b, 1842.-Brauer, Verhd. k. k. zool.-bot. Gesell., Wien, XVIII, p. 716, 1868.-Selys, Enum. Odon. Madag. (in Pollen \& Van Dam's Recherches sur la Faune de Madag., 5me

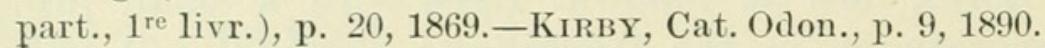

Palpopleura confusa, Rambur, Névropt., p. 133, pl. 3, fig. 3c, 1842.

Locality.-One male in the National Museum collection, from Zanzibar.

${ }^{1}$ Berl. Ent. Zeit., XXXIII, 1890, p. 356.

${ }^{2}$ For Zygonyx, I infer this from the general tone of his article in Berl. Ent. Zeit., XXXIII, pp. 280-284, and for Schizonyx are his own words, "der mir unbekannten Schizonyx luctifera" (Berl. Ent. Zeit., XXIII, p. 282).

${ }^{3}$ Ann. Soc. Ent. Belg., XXXV, 1891, p. cexxviii. 
TRITHEMIS FERRUGARIA, Rambur.

Libellula ferrugaria, Rambur, Névropt., p. 82, 1842.

Trithemis ferrugaria, Kirby, Cat. Odon., p. 19, 1890.

Locality.-Seven males and two females, from Kilimanjaro.

Male.-Vertex, frons, nasus, and occiput reddish brown. Tip of vertex slightly concave from side to side. Frons very similar to that of Libellula erythraa, Brullé; deeply grooved on the median line, forming: a well-marked tubercle on either side, which is separated from the vertex by a transverse groove. Rhinarium, labrum, labium, and rear of head ocher brown.

Thorax brown. Hind margin of prothorax more or less bilobed.

Feet light brown or reddish, spines black.

Abdomen trigonal, not inflated at the base when viewed from above, and but little when viewed from the side, gradually tapering to the apex; brown (probably reddish in life), marked with black as follows: A line on the dorsal carina of the middle third of 3 (and sometimes of 2), of the basal half of $4-7$ and of the greater part of 8 ; a median dorsal spot or line on the greater part of 9 ; a

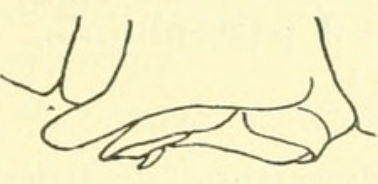

Fig. 4.

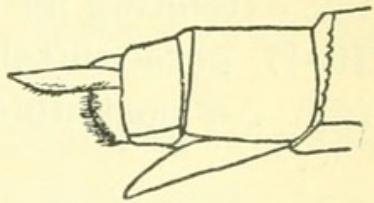

Fig. 5 .

TRITHEMIS FERRUGARIA.

(4) Side view of genitalia, male; (5) Side view of last two abdominal seg. ments and rulvar lamina, female. line on the middle of the lateral carinæ of 3-8. Venter black. Sometimes a black spot on sides of 2 . Two and three with the usual median transverse carina each.

Genitalia of 2 a little prominent, very similar to those of erythrea, Brullé. Anterior lamina short, margin entire, straight. Hamule with the internal branch rather slender, simple, curved inward and backward, apex acute; external branch longer, thicker, somewhat lamellate, directed backward, concave from side to side anteriorly; apex broad, moderately acute, extreme tip being on the postero external side and directed outward. Genital lobe projecting as far ventrally as the external hamular branch, apex rounded.

Superior appendages reddish, a little longer than 9 ; straight, dilated on the inner and lower sides before the apex, which is acute, and bearing on the lower surface $8-10$ black denticles. Inferior appendage $\frac{1}{8}-\frac{1}{10}$ shorter, about half as wide at its base as it is long, tapering gradually to the apex, which is slightly upeurved, ending in the usual two denticles, which reach beyond the last denticle on the superiors.

Wings hyaline; reticulation reddish brown near the anterior margin, becoming blackish posteriorly. Pterostigma light brown. Membranule gray. Front wings with a yellowish tinge at extreme base. Hind wings with a ferrugineous basal spot, extending outward to the arculus and from the anterior margin nearly to the posterior. Sectors 
of the arculus stalked; one cross vein in the median space, ${ }^{1}$ placed nearer the base than the first antecubital; no hypertrigonals; nodal sector almost straight. Front wings with 10-12 antecubitals, the last one not continuous, 6-9 postcubitais; triangle with one cross vein; internal triangle of three cells, three rows of posttriangular cells. Hind wings with 8-9 antecubitals, 7-10 postcubitals, triangle free, no internal triangle, two rows of posttriangular cells, sectors of the triangle arising from the same point. ${ }^{2}$

Female.-Vertex and frons shaped as in male, luteous. Occiput dark brown. Nasus, rhinarium and lips yellow. Rear of head, thorax, feet and abdomen luteous. Hind margin of prothorax slightly truncate, with a trace of a median emargination. Thorax paler on the sides. Abdomen with black marks similar to those of male. Appendages simple, straight, luteous, not quite as long as 9. Vulvar lamina produced a little beyond the apex of 10, its margin entire; apex rounded. Wings similar to those of male; basal ferrugineous spot on hind wings not extending as far toward the posterior margin. Front wings with 10-11 antecubitals, 8-9 posteubitals. Hind wings with 8-9 antecubitals, $7-9$ posteubitals. ${ }^{3}$

Measurements of Trithemis ferrugaria.

\begin{tabular}{|c|c|c|}
\hline & Male. & Female. \\
\hline 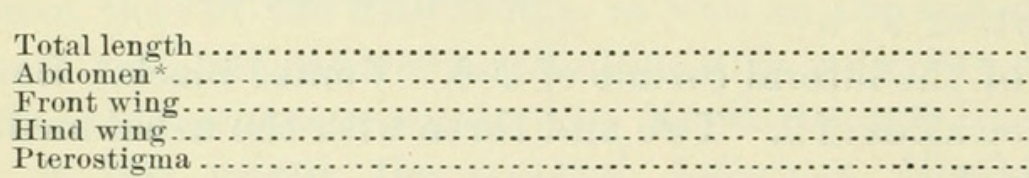 & 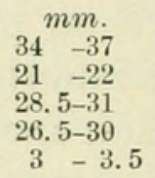 & $\begin{array}{c}m m . \\
34 \\
22 \\
30-30.5 \\
28-28.5 \\
3.5\end{array}$ \\
\hline
\end{tabular}

Here, as always, I include the appendages.

Rambur has described only the male of this species. His description is mainly comparative, noting the differences from T. erythrae, Brullé (T. ferruginea, Vander Linden) as follows:

A little smaller than T. ferruginea, resembling it extremely; of a lighter color, red, depending on the age. Head having the face and the vertex a little less projecting. Posterior lobe of the prothorax sensibly projecting, slightly notched in the middle (projecting in T. ferruginea). Abdomen much less broad, less depressed, trigonal, narrow posteriorly, reddish, having small, black, long, and narrow spots

${ }^{1}$ Variations: One male has two such median cross veins in left frout wing and in both hind wings, and has triangle of right hind wing with one cross vein. Another male has two median cross veins in right hind wing, and the triangle of left hind wing with one cross vein. A third male has two median cross veins on left hind wing. A fourth male has both hind wings with two median cross veins. The additional median cross vein is always on the outer (apical) side of the normal.

${ }^{2}$ Variation: On right hind wing of one male the upper sector of the triangle arises from the lower sector a short distance from the origin of the latter.

${ }^{3}$ Variations in venation of these two females: One has right hind wing with triangle having one cross vein, and both hind wings with the sectors of the triangle separated a short distance at their origins. The other has the left hind wing with two median cross veins. 
on the lateral and dorsal border; hamules having the internal branch longer and the external shorter; substylar piece [=inferior appendage] narrower. Wings transparent, with the veins red and the base a little spotted with reddish yellow; pterostigma smaller, ferrugineous; ten to eleven veins in the first costal space; membranule reddish, a little obscure.

These differences hold good for the present specimens. The size of T. erythrea is: Total length, male, 37-41.5; female, 33-38; abdomen, male, 23-27.5; female, 20.5-25.5; hind wing, 26-30.5, pterostigma, 3.5-4. The fifth abdominal segment at apex measures nearly $4 \mathrm{~mm}$. in T. erythraa, $2 \mathrm{~mm}$. in $T$. ferrugaria. The internal hamular branch does not appear to me to be longer than in T. erythrcea, but the external branch is proportionately shorter. A figure of the genitalia of a male specimen of $T$. ferrugaria accompanies this paper. A similar figure for $T$. erythrce accompanies my report on the Odonata of the United States Eclipse Expedition to the Congo.

The female of $T$. ferrugaria may easily be distinguished from that of T. erythrea, as the latter has the vulvar lamina more nearly at right angles to the abdomen and reaching backward no farther than the middle of the ninth abdominal segment.

A comparison of specimens of T. ferrugaria and T. erythrcea with the generic characters given by Mr. Kirby ${ }^{1}$ for Trithemis and Crocothemis, to which these species are respectively referred by him, ${ }^{2}$ shows the only difference to be that Trithemis has the "abdomen moderately slender," while Crocothemis has the "abdomen stout." I have not been able to detect any other generic character between these two species. In view of their close relationship, as shown above, the claims of Crocothemis to generic rank may well be doubted.

\section{Genus ORTHETRUM (Newman) Karsch.}

The three following species agree with the characters laid down for Orthetrum by Dr. Karsch, ${ }^{3}$ viz:

Last antecubital continuous, hind wings with only one cross vein in the median space, sectors of the arculus distinctly stalked, basal side of the cardinal cell [i. e., discoidal triangle] in the hind wings in the prolongation of the arculus; nodal sector strongly waved beyond the middle; membranule large, vertex in the male distinctly bifid, discoidal field of the front wings of three to five rows of cells varying according to the size of the species; sides of the eighth abdominal segment in the female dilated, frons anteriorly flat, shieldlike, marginate; abdomen thin, often very slender, often swollen at the base; hind tibiæ with a few (5-8) widely separated, very strong spines on the outer, under side.

Dr. Karsch adds that the upper sector of the triangle in the hind wings arises on the outer side of the triangle always distinctly removed

\footnotetext{
${ }^{1}$ Trans. Zool. Soc., London, XII, pp. 278, 279, 1889.

${ }^{2}$ Cat. Odon., pp. 19, 21.

${ }^{3}$ Ent. Nach., XVII, p. 58.
} 
from the hind angle. A comparison of fifty-one specimens of twelve species of Orthetrum now available shows this character not to be generic. Only nine specimens, representing four species, can be said to have the sectors of the triangle distinctly separated at their origin; the remaining forty-two specimens, representing nine species, have the sectors more or less united. It is only fair to state, however, that among these latter are some specimens which puzzle me to say whether the sectors are to be spoken of as united or separated. Moreover, there are specimens which differ in this particular, in the right and left hind wings; and of at least two species, specimens occur having sectors united and others with the sectors separated.

The terms "shield-like, marginate," applied to the frons, refer to the demarcation of the anterior face from the sides by a vertical carina on each side, the two carinæ being united at their lower ends by a horizontal carina just above the suture, separating the frons from the nasus.

\section{ORTHETRUM TRUNCATUM, new species.}

Male.-Vertex dark brown. Frons anteriorly and superiorly dark olive brown, sides yellow, a black line in front of the eyes. Epistoma, lips, and occiput luteous; mentum varying from luteous to black. Nasus sometimes of the same color as the frons.

Prothorax brownish; posterior lobe as broad as the median lobe, its hind margin slightly emarginate at the middle.

Dorsum of thorax somewhat luteous, a rather narrow antehumeral black stripe reaching the anterior margin below, and almost the wing bases above; summit of the median carina, edges of antealar sinuses, ete., black; a longitudinal dorsal interalar whitish stripe. Sides reddish-brown, an oblique pale-yellow stripe immediately behind the first and second lateral sutures, not reaching the bases of the feet below, clearly defined in their lower halves by a narrow circumscribing black stripe; upper halves not circumscribed, ill defined. Behind the second yellow stripe the color of the sides is pale olive. Pectus obscure, luteous. Latero-ventral metathoracic carina of same color as sides in younger males; black in older ones. In older males the colors of the thorax are more or less concealed by pruinose.

Feet black, upper surface of first femora and first and second tibiæ luteous in younger males.

Abdomen viewed from above somewhat dilated at the base; moderately narrowed at the base of 4 , gradually becoming slightly wider to the apex of 6 ; thence narrowing very slightly to the apex; viewed from the side, noticeably dilated at the base, but not constricted; pruinose in all the specimeus examined.

Superior appendages black, not as long as the last two segments; viewed from above, straight, only slightly dilated before the apex, which is moderately acute; viewed from the side, each is directed downward, thickest at two-thirds its length, lower side with 7-8 denticles; apex hardly upcurved. Inferior appendage two-thirds as long, 
luteous, edged with black, broad; apex emarginate when viewed from below, ending in two upcurved denticles which do not reach the last denticle on the superiors.

Genitalia of 2 moderately prominent. Anterior lamina slightly more prominent than hamule or genital lobe, its apex slightly emarginate in the middle. Hamule bifid, branches widely divergent; internal brauch when viewed from the side considerably thicker than the anterior lamina, its apex almost truncate, somewhat hooked on its outer side, a little less prominent than the anterior lamina; external branch much shorter, lying against the ventral margin of 2 ; apex rounded. Genital lobe rather broad, about as prominent as, or less so than, the internal hamular branch.

Wings hyaline, somewhat smoky; reticulation black, costa luteous anteriorly. Hind wings only with a small yellowish cloud alongside the membranule, never extending outward farther than a single cell. Pterostigma 4-5 times as long as wide; bright ocher yellow. Membranule cinereous, whitish at the base and along the alar side. Front wings with 11-14 antecubitals, 8-11 postcubitals, one hypertrigonal, one median cross vein, triangle with one cross vein, three rows of posttriangular cells, internal triangle of three cells. Hind

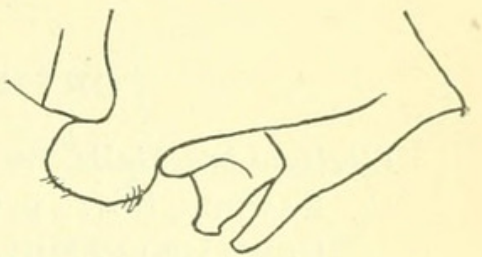

Fig. 6.

ORTHETRUM TRUNCATUM.

Side view of genitalıa. wings with 9-10 antecubitals, 9-12 postcubitals, no hypertrigonals; triangle free, median cross vein placed nearer the base than the first antecubital; two rows of posttriangular cells increasing. no internal triangle; sectors of the triangle united at their origins. ${ }^{1}$

The female is unknown to me.

Measurements.-Total length, 40.5-43 mm. Abdomen, 27-30. Front wing, 30-33.5. Hind wing, 29-32.5. Pterostigma, 3-3.25. Width of abdomen at base, 2.5 ; at base of $4,1.5$; at apex of 6,2 .

Locality.-Six males in the National Museum collection, from Kilimanjaro.

At first, I had referred these specimens to O. chrysostigma, Burmeister (O. barbara, Selys). Mr. W. F. Kirby has kindly compared a tracing of the accompanying figure of the genitalia of $O$. truncatum with a male O. chrysostigma in the British Museum, with the result that the latter has the anterior lamina very short and slender (much less prominent than the hamule and less than the genital lobe); the hamule decidedly more prominent than the genital lobe, and in general "the genitalia agree with M. Albarda's ${ }^{2}$ description as far as it goes." There are

${ }^{1}$ Variations in reticulation in the front wings: One male has no hypertrigonals in left wing; another has two cross veins in the right wing; a third has the internal triangle of two cells in the left wing. In the hind wings, the posttriangular series sometimes commences with three cells.

${ }^{2}$ Cf. Albarda, Ann. Soc. Ent. Belg., XXXI, p. 19, 1887.

Proc. N. M. 95 $-9$ 
also some differences in color from 0 . chrysostigma, but these are of comparatively little importance.

It is quite possible that the two species of Orthetrum described as new in this paper are in reality identical with some of the species described by Burmeister or Rambur. As, however, I am unable to point out such an identity from the existing descriptions, it seems better to describe and figure the present material under new names than to run the risk of erroneous identifications. It is hoped that the present descriptions and figures will sufficiently characterize the species in question, so that those having access to types of previously described species may perceive the identity, if it exist. The genus Orthetrum is a difficult one, and a revision of its species, based on abundant material, is greatly to be desired. I would suggest that the most reliable specific characters are to be found in the genitalia of the male and the vulvar lamina of the female, on the lines adopted by M. Albarda.

\section{ORTHETRUM BRACHIALE, Beauvois.}

Libellula brachialis, Beauvors, Ins. Afr. Amér., p. 171, Neur., pl. 2, fig. 3, 1805.Rambur, Névr., p. 62, 1842.-Selys, Ann. Soc. Ent. Belg., XXXI, p. 21,1887.Gerstäcker, Mitt. Naturh. Mus. Hamburg, IX, 1, p. 5, 1891.

Orthetrum brachiale, KirBY, Cat. Odon., p. 36, 1890.

Male.-Vertex dark brown or black. Frons roughly punctate, varying from light olive green to dark brown, according to age; the carinæ margining the "shield" are yellow in younger individuals; of the same color as the frons in older ones. Nasus and rhinarium light olive green to obscure luteous, according to age. Labrum obscure luteous, its margin sometimes black. Labium varying from luteous, unspotted, to the mentum black; lobes with a black spot on the inner margin. Occiput dark brown or black.

Prothorax pale green with small brown marks in younger males, pruinose in older; hind margin more or less emarginate in the middle.

Thorax (in dry specimens at least) light green in young males; brown and paler on the sides in those somewhat older; median dorsal carina blackish at apex; dorsum of thorax somewhat darker alongside of this carina, and occasionally forming a complete stripe from the anterior border to the antealar sinus; a blackish antehumeral stripe not reaching the anterior mesothoracic border below nor the antealar sinus above; a complete humeral stripe in the young males, giving off an anterior branch halfway up, in older males the humeral stripe exists only near the feet; a short black stripe in front of the spiracle, and on the lower part of the second lateral suture; latero-ventral metathoracic carina shining black. In old males the thorax is almost entirely pruinose.

Feet black, trochanters, bases of femora, front femora inferiorly, second tibiæ superiorly, often pale.

Abdomen, viewed from above, inflated at the base, compressed, narrowing to the base of 4 , thence widening to 6 , thence tapering to apex; 
10 as wide or wider than base of 4 . In the young males the colors are: 1 light olive green, dorsum with a dark brown spot each side; 2 similar, dorsal spots, darker in front of and widest at the black, transverse median carina; 3 and 4 light brown, dorsum with a darker stripe each side reaching the apex but not the base; 5 and 6 blackish, with a light brown spot on each side of dorsum at middle; 7-10 black dorsally; 1-4 light brown ventrally; 4-7 blackish ventrally, an elongate brown spot on the middle, each side of the venter; with age, the abdomen becomes more and more pruinose.

Superior appendages about twice as long as 10, yellow in young, darker and even black in older males; viewed from above, each appendage is straight, dilated on the inner side before the apex, which is acute; viewed from the side, each is directed downward (but the apex slightly upward), with 8 or 9 denticles on the underside. Inferior appendage about a third shorter, luteous; viewed from the side, it forms a dorsally concave curve from base to apex, ending in the usual two denticles, which do not reach as far as the last denticle of the superiors (in only one male do

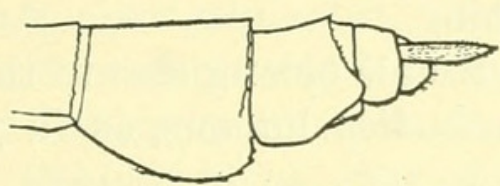

Fig. 7.

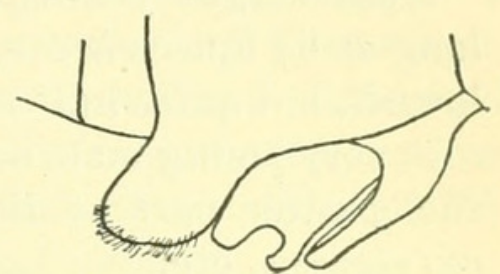

Fig. 8 .

ORTHETRUM BRACHIALE.

(7) Side view of last three abdominal segments, female; (8) Side view of genitalia, male.

they reach farther); viewed from below, the appendage is broad, triangular; apex black, truncated, slightly emarginate.

Genitalia of 2 prominent. Anterior lamina much as in O. brunnea, with sides rounded to the apex, which is truncated and (usually) slightly emarginate. Hamule with apex bifid, branches parallel, of equal length; ${ }^{1}$ internal branch rather slender, apex slightly hooked and directed outward; external branch twice as thick, apex rounded; genital lobe as pronounced as in $O$. coerulescens, broad, apex rounded; the internal hamular branch projects slightly farther than the anterior lamina or the genital lobe.

Wings hyaline, with a slight smoky tinge, especially near the apex. Reticulation dark brown, costa yellowish anteriorly as far as the pterostigma. Hind wings with a small rufescent basal spot reaching: from the submedian to the apex of the membranule and outward for one or two cells. Pterostigma dark brown, four times as long as broad. Membranule blackish brown, whitish at extreme base. Front wings with 12-16 antecubitals, 8-12 postcubitals, one hypertrigonal; triangle with one cross vein, internal triangle of three cells, three rows of posttriangular cells. Hind wings with 9-13 antecubitals, 10-13 postcubitals, no hypertrigonals, sectors of the triangle united or a little separated at

J Owing to the oblique position of the hamule, however, the internal branch appears more prominent than the external. 
their origin ${ }^{1}$ two (or three) rows of posttriangular cells; triangle free, no internal triangle.

The female differs from the male as follows:

Colors agree generally with those of younger males.

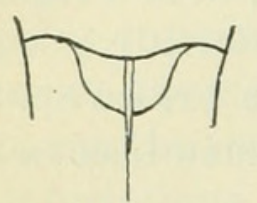

Fig. 9.

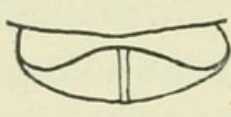

Fig. 10. orthetrum brachiale, Female.

(9) Ventral view of apical margin of vulvar lamına; (10) A pical margın of vulvar lamina. viewed from behind. ginate; this bent portion has a very small median carina. Median ventral earina of 9 well developed.

Appendages yellow, more than twice as long as 10, but hardly as long as 9 ; apices acute, slightly brownish; tubercle between them yellowish, not quite half as long.

A very young male and female belong also to this species; they have the greater part of their bodies luteous, as in young imagoes of $O$. ccrulescens, etce.

Measurements of Orthetrum brachiale.

\begin{tabular}{|c|c|c|}
\hline & Male. & Female. \\
\hline Total length............... & ${ }_{41.5-48.5}^{m m}$ & ${ }_{43-44}^{m m}$. \\
\hline 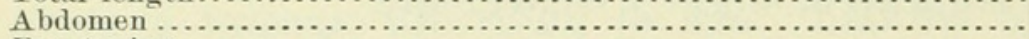 & $28-33.5$ & 30 \\
\hline 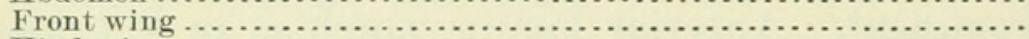 & $32-37$ & $33-36$ \\
\hline 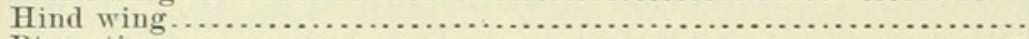 & $31-36$ & $32-35$ \\
\hline 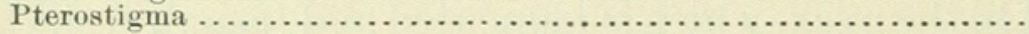 & $3-3.5$ & $3-4$ \\
\hline
\end{tabular}

Locality.-Two males and one female in the National Museum collection, from Zanzibar (one of these also marked "Taviite, Jan., '89"); fourteen males, one female in the National Museum collection, from Kilimanjaro.

As indicated, the identification of this species as O. brachiale is somewhat doubtful; I have relied chiefly upon Baron de Selys' brief comparative description. ${ }^{2}$ No detailed description of $O$. brachiale has hitherto been published. Dr. Hagen kindly examined one male and the female of the specimens from Zanzibar, and in September, 1890, wrote te me of them: "It is, I believe, the same species quoted by Burmeister (p. 857) as L. sabina (not published) from the Comores Isles, perhaps =L. barbara?." L. sabina, Burmeister, is not sabina, Drury, and the present species is not barbara, Selys (=chrysostigma, Burmeister). Dr.

'Variations in reticulation: Two males have no hypertrigonal in the right front wing; one has two hypertrigonals in the left front wing; two have a cross vein in the discoidal triangle of the left hind wing.

${ }^{2}$ Ann. Soc. Ent. Belg., XXXI, p. 21, 1887. 
Hagen's subsequent illness has prevented me from seeking further aid from him. In my report on the Odonata collected by the United States Eclipse Expedition to the Congo, I described a species under the name of capensis. I am now doubtful whether it is distinct from the present species, but the specimen is no longer before me. ${ }^{1}$

\section{ORTHETRUM ABBOTTII, new species.}

Wings hyaline, reticulation brownish, costa and some cross veins near base, yellowish; an extremely small fulvous cloud at base of the long veins; pterostigma yellow, its veins black, surmounting 2-3 cells; membranule whitish, darker on its free border. Front wings with 12-13 antecubitals, 9-10 posteubitals, one hypertrigonal; median cross vein more distant than first antecubital. Hind wings with 10 antecubitals, 9-10 postcubitals, no hypertrigonals, median cross vein nearer than the first antecubital; sectors of the triangle distinctly separated at their origins. Three rows of posttriangular cells in all four wings.

Male.-Vertex black, apex truncated. Frons, nasus, and rhinarium pale green; frons darker anteriorly between the two vertical carinæ and at the middle of the upper surface. A black line in front of the eyes. Lips yellow. Occiput black, rear of head yellow.

Prothorax pruinose, its hind margin slightly bilobed.

Thorax pruinose, median dorsal carina black; an oblique greenish yellow band on the sides just behind the spiracle followed by a black oblique band at the second lateral suture; posterior to this latter band the color is light green; latero-ventral metathoracic carina greenish.

Abdomen rather slender; viewed from above, base moderately inflated, becoming narrower to the base of 3 , thence widening to 6 , thence narrowing to apex; black, pruinose, some pale spots on the sides of 1,2 , and base of 3 .

Superior appendages not as long as the last two segments, black, slender, straight, denticulated below, apices moderately acute. Inferior appendage one-fourth shorter, obscure luteous, edged with black, rather broad, its apex broad (one-third of length), rounded when viewed from below, ending in two denticles directed upward, not reaching as far as the last denticle of the lower side of the superiors.

Genitalia of 2 prominent. Anterior lamina more prominent than any other piece, swollen anteriorly when viewed in profile, the swollen portion covered with minute denticles; apex distinctly emarginate

\footnotetext{
${ }^{1}$ One male of the lot of brachiale from Kilimanjaro has the following imperfections in structure: The left hamule is normal, but the right hamule is entirely wanting, apparently not having developed. The anterior lamina is apparently represented only by a tubercle, better developed on the right side, and not projecting as far as the level of the point of bifurcation of the left hamule. The left superior appendage is normal, but the right one is nearly a third shorter, although with the same acute apex as these appendages normally have, and bears no inferior denticles. The left Iateral margin of 8 is dilated as in the female, and there is a rudiment of a similar dilatation on the right side. In all other particulars this male seems to be normal.
} 
from side to side. Hamule with its apex bifid; internal branch rather slender, apex blunt, external branch shorter, twice as broad, apex truncated. Genital lobe not as prominent as the internal hamular branch. Feet black, femora yellow superiorly.

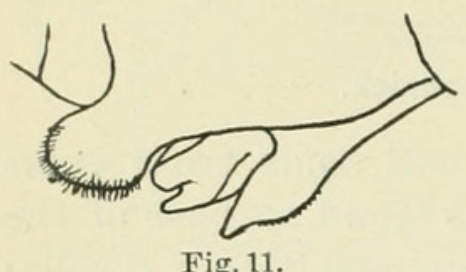

orthetrum ABвottir, Male.

Side view of genitalia.

Female.-Face and lips luteous, a black line in front of the eyes. Vertex and occiput dark brown. Rear of the head luteous.

Thorax luteous; summit of the median dorsal carina, a short line at the summit of the first and second lateral sutures, rim of the spiracle and margins of antealar sinus, black.

Abdomen of almost equal width throughout, luteous, carinæ and anterior sutures black; a lateral marginal black stripe on 4-7; dorsum of 8 black with a luteous stripe each side, except at apex; dorsum of 9 black; dorsum of 10 black with two small apical luteous spots. Lateral margins of 8 somewhat dilated (about as much as in O. brunnea).

Appendages straight, simple, black, a little longer than 10; tubercle between them luteous.

Vulvar lamina simple, margin straight, entire, not projecting farther than the apex of 8 .

Feet: Femora superiorly luteous, inferiorly black; tibiæ superiorly bright yellow, inferiorly black; tarsi black.

Measurements of Orthetrum abbottii.

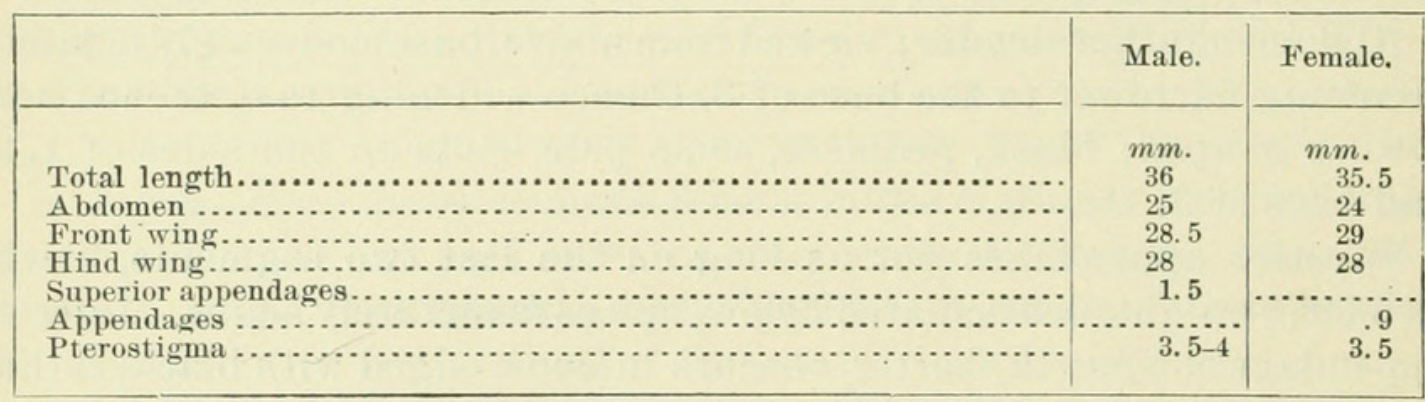

Locality.-One male and one female in the National Museum collection, from Kilimanjaro.

\section{ORTHETRUM WRIGHTII, Selys.}

Libellula wrightii, Selys, Ann. Soc. Ent. Belg., XII, p. 96; Ann. Mag. Nat. Hist. (4), III, p. 272, 1869.

Orthetrum wrightii, KIRBY, Cat. Odon., p. 182, 1890.

Libellula desjardinsii, Selys, in Pollen \& Van Dam, Faune Madag., Ins., p. 22, 1869; Rev. Mag. Zool., 1872, p. 182.

Male._Face pale olive or luteous. Frons blue black anteriorly and on the sides, which is continuous, with a black stripe in front of the eyes and vertex, the black thus inclosing a pale olive spot on the upper surface of the frons, and also a small yellow spot on the sides inferiorly; below the horizontal carina luteous. Labrum luteous, free margins 
edged with black, and traversed by a median black stripe. Labium: Mentum and inner margin of lobes black, remainder of lobes yellowish. Vertex and occiput black. Rear of eyes luteous, with two black spots. Anterior and middle lobes of prothorax black, their anterior margins yellowish. Posterior lobe obscure yellowish, barely notched in the middle of the hind margin.

Thorax yellowish brown, with black stripes as follows: A broad median dorsal reaching the antealar sinuses, an antehumeral not reaching the sinus; a broader humeral; an oblique lateral, in which the spiracle lies, and which is closely connected with a similar parallel stripe in front of itself; a stripe on the second lateral suture, and an incomplete oblique stripe behind the suture; these stripes are more or less confluent below; the median dorsal and antehumeral are connected inferiorly by a transverse anterior mesothoracic stripe. Latero-ventral metathoracic carina black. Interalar pieces mostly yellowish. Pectus obscure luteous.

Feet black, coxæ marked with luteous, first femora luteous inferiorly. Hind tibiæ with 7 outer, 10-11 inner spines.

Abdomen shaped as in O. brachiale, Beauvois; black, marked with yellowish or reddish brown, as follows: 1 with a small dorsal and a small lateral spot; 2 with a larger dorsal and two lateral spots; 3 with two pairs of dorsal spots, one pair smaller and in front of the middle transverse (supplementary) carina, the other larger and behind the carina, and a lateral spot; 4-6 with a dorsal spot on each side of longitudinal carina, near the middle of the segments; on 5 and 6 each spot is almost divided longitudinally into two; 3-8 with a ventral spot on each side.

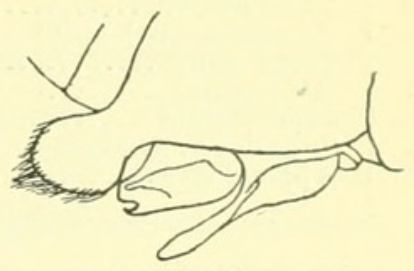

Fig. 12.

ORthetrum Wrightir, Male. Side view of genitalia of second abdominal segment.

Superior appendages yellowish, not as long as the last two segments; of the shape described for $O$. truncatum; inferior denticles very small. Inferior appendage yellowish, similar to that of $O$. truncatum.

Genitalia of 2 rather prominent, black. Anterior lamina longer than any other piece, its apex rounded, barely notched; viewed from the side it is quite slender. Hamule with apex bifid, branches approximately of equal length when viewed laterally ; internal (anterior) branch slender, with a very acute apex directed outward; external branch much broader, somewhat lamellar, apex broad, truncate, angles rounded. Genital lobe rather broad, rounded, projecting equally with the internal hamular branch.

Wings hyaline, only the faintest tinge of yellow at extreme base of posteriors. Pterostigma dark brown. Membranule cinereous, slightly whitish at base. Reticulation black. Front wings with 12-13 antecubitals, 9 postcubitals, one hypertrigonal; discoidal triangle of two cells; internal triangle of three cells; three rows of posttriangular cells; one median cross vein. Hind wings with 10 antecubitals, 10-11 postcubitals, no hypertrigonals, one median cross vein ( 2 in left wing), 
triangle free, two posttriangular rows; inner side of triangle lying slightly beyond the arculus (a distance equal to that part of the areulus from its lower end to the origin of its sectors); sectors of the triangle united at their origin.

The female differs from the maıe as follows:

Lower half of median dorsal carina yellowish. Yellow of thorax brighter. Abdomen shaped much as in the female of 0 . brachiale; 2 with a small dorsal yellow spot in front of the spot corresponding to that described for the male; 7 with a small lateral spot; 10 with a small dorsal spot. Sides of 8 dilated. Appendages a little longer than 10, yellow, straight, apex acute. Vulvar lamina not prolonged beyond apex of 8; margin entire, not bent in the manner described for $O$. brachiale. Front wings with 13-14 antecubitals, 8-9 posteubitals. Hind wings with $10-11$ antecubitals, 10 postcubitals, one median cross vein, inner side of triangle in prolongation of arculus; sectors of triangle separated (right wing) or united (left wing) at their origins.

Measurements of Orthetrum wrightii.

\begin{tabular}{|c|c|c|}
\hline & Male. & Female. \\
\hline 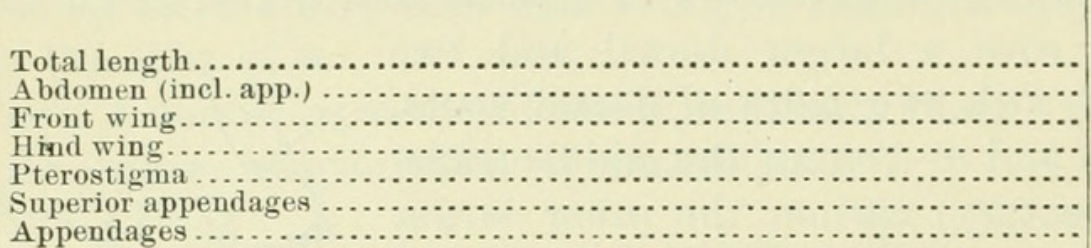 & $\begin{array}{c}m m . \\
41 \\
28 \\
30 \\
29 \\
3 \\
1.75 \\
\ldots \ldots \ldots\end{array}$ & $\begin{array}{l}\operatorname{mm} . \\
40 \\
28 \\
30 \\
29 \\
3 \\
\ldots \\
1\end{array}$ \\
\hline
\end{tabular}

Locality.-One male and one female in the National Museum collection, from the Seychelles, collected by Dr. W. L. Abbott.

\section{ONYCHOGOMPHUS COGNATUS, Rambur.}

Gomphus cognatus, RAmbur, Névr., p. 167, 1842.

Onychogomphus cognatus, Selys, Bull. Acad. Roy. Brux., XXI, Pt. II, p. 38 (Syn. Gomph., p. 19), 1854; Monog. Gomph., p. 56, 1858.-Karsch, Ent. Nach., XVI, p. $377,1890$.

Lindenia cognata, KirBy, Cat. Odon., p. 59, 1890.

Two males in the National Museum collection, from Kilimanjai'o, belong to this species, but differ from the description of the male given by Baron de Selys ${ }^{1}$ as follows:

The dark marks of the face and lips are brown. In one male the "large raie transverse en avant, au sommet du front" is wanting.

There are no spines on the occiput.

There is a group of 6-8 black denticles on each side of the upper surface of the frons.

The thoracic stripes are brown; the median dorsal bands are not broad and do not join the antehumeral bands; there is a stripe on the second lateral suture, and a stripe from the spiracle to between the 
second and third coxæ; the humeral stripe is narrow and not well defined.

The coloring of abdominal segments $2-7$ is more like that of the female of the Stockholm collection than of the male.

Stripes on the feet brown, rather ill defined.

Antecubitals 11-12 on front wings, 8-9 on hind wings, 6-8 posteubitals on all wings. First and fifth antecubitals thicker on all wings. No subcostal cross vein (of Karsch). Three cells after the triangles, then two rows.

Measurements.-Total length, $43 \mathrm{~mm}$. Abdomen, 33. Front wing, 26-27. Hind wing, 25-26. Pterostigma, 3.5. Superior appendages, 3.

One male has lost the last four abdominal segments.

In spite of the differences described above, I believe these specimens to belong to $O$. cognatus (Rambur) Selys, because the appendages, the size of the body, and the pterostigma agree with the description thereof. The most serious differences are the absence of the occipital spines and the presence of the frontal denticles.

\section{ANAX RUTHERFORDI, McLachlan.}

Anax rutherfordi, MeLachlan, Ent. Mo. Mag., XX, p. 128, 1883.-KIRBY, Cat. Odon., p. 85,1890 .

Female.-Frons, nasus, and rhinarium pale greenish yellow; no spot on the frons. Labrum and labium a little more obscure. Free margin of the labrum slightly edged with blackish. Mandibles exteriorly pale yellow, their tips black. Vertex blackish, its tip light brown, forming a crescent, concave anteriorly, when viewed from above. Occiput and rear of the head brownish yellow; hind margin of the occiput concave.

Colors of the thorax changed; perhaps greenish on the side, darker on dorsum.

Abdomen stout, base inflated, thence tapering gradualiy to 7, apex a little wider. A supplementary lateral carina on 6-10, but faintly marked on 6 and 10. Between the two lateral carina of each side of 6-9 are some blackish marks. A cluster of fine black denticles on the median apical dorsum of 2 ; ventral apex of 10 with numerons slightly larger black denticles. General color of the abdomen reddish brown in the dried specimen; a basal black spot on 1; an apical black spot on 2-8, interrupted and divided into two spots by the dorsal carina on 5-7; a median dorsal black spot on $9 ; 10$ paler than the preceding segments, apparently unspotted.

Appendages leaflike, reddish brown, a little longer than the last two segments, apices moderately acute.

Femora reddish, tibiæ and tarsi black.

Wings hyaline, smoky along the posterior margin. Reticulation reddish brown about as far as the nodus, then becoming dark brown or black; the costa remains a light brown, however, for nearly its entire length. A yellow cloud at the base of all the wings between the costa 
and the postcostal, not reaching as far as the first antecubital. Pterostigma dark reddish brown, surmounting 3-4 cells, its internal vein prolonged to the principal sector. Membranule with basal half white, apical half cinereous. Front wings with 21 antecubitals, the 1st and 7 th thicker than the others; $11 \mathrm{R}, 10 \mathrm{~L}$ postcubitals, 4 hypertrigouals; triangles of 6 cells, 2 cells being on the inner side; internal triangle present, with one cross vein; three other median cross veins, all nearer the base than the arculus; subnodal sector with six inferior branchlets (including the inferior terminal fork); arculus joining the median nerve at the second antecubital. Hind wings with $15 \mathrm{R}, 14 \mathrm{~L}$ antecubitals, 1st and 7th thicker; $12 \mathrm{R}, 14 \mathrm{~L}$ postcubitals, $4 \mathrm{R}, 3 \mathrm{~L}$ hypertrigonals, triangle of $6 \mathrm{R}, 5 \mathrm{~L}$ cells (but with a rudiment of the vein forming the 6th) as in front wings; internal triangle present, with one cross vein; two other median cross veins, nearer than the arculus; subnodal sector and arculus as above; no anal triaugle.

Measurements.-Length, $79 \mathrm{~mm}$. Abdomen, 59. Front wing, 60 . Hind wing, 59. Appendages, 5.5. Pterostigma, 5.5. Breadth of head, 10.5

Locality.-One female in the National Museum collection, from Kilimanjaro.

The female of this species has not hitherto been described. Mr. McLachlan's types were two males from Sierra Leone. The female above described seems to belong to the same species. The two males are stated to agree in size with $A$. speratus, Hagen, ${ }^{1}$ whose measurements are: Length, $72 \mathrm{~mm}$; abdomen, 51; wings, 56 ; pterostigma, 5.5 ; appendages, 7 ; alar expanse, 116; width of head, 10.5. The present female is somewhat larger, but a greater range of size is known for other species of Anax (longipes, junius, etc.). That A. rutherfordi should be found at a locality so distant from Sierra Leone as Kilimanjaro is in accordance with the strong powers of flight possessed by the species of Anax and with what we know of the distribution of other African species of this genus. Mr. McLachlan ${ }^{2}$ records A. goliath, Selys, from Abyssinia and from Jellah Caffee, in West Africa. The types of Selys came from Madagascar. Hemianax ephippigerus, Burmeister, occurs in the Congo and Senegal countries, Morocco, Algeria, Egypt, Western Asia, Turkestan, Arabia, the Himalayas, in Moldavia, and occasionally elsewhere in Europe. ${ }^{3}$

\section{ÆSCHNA RILEYI, new species.}

Female.-Frons, nasus, rhinarium, and lips brown. Frons darker above, with a yellow half ring inclosing a nearly round dark-brown spot which reaches to the vertex; a yellow line in front of the eyes becomes confluent with this half ring, which latter is slightly inter-

${ }^{1}$ Verhd. zool.- bot. Gesell. Wien, 1867, p. 46.

${ }^{2}$ Ent. Mo. Mag., XXI, p. 131.

${ }^{3}$ Selys, Ann. Soc. Ent. Belg., XXXI, p. 37, 1887. 
rupted anteriorly, so that the inclosed round spot becomes confluent with the brown of the frons at this point. Vertex dark brown, with a crescentlike yellow tip; concave anteriorly. Occiput triangular, yellow above and behind, its lateral angles and the rear of the head black.

Thorax brown, dorsum with a short antehumeral yellow line from the anterior mesothoracic border halfway up to the antealar sinus; a very narrow yellow humeral line, slightly wider at the sinus. Sides with two broad oblique yellow bands, margined with shining black, one beginning under each pair of wings, but not attaining the bases of the feet. Antealar sinuses and some spots on interalar space yellow.

Feet: Bases and femora reddish brown, apices of femora, tibiæ, and tarsi black. Spines of the hind tibiæ on the inner and outer sides equal in number and length.

Abdomen distorted in this specimen, but apparently inflated at the base, thence gradually tapering to the apex; brown in the dried condition and marked with yellow as follows: A trans. verse stripe margined with black on each side, near the middle of the dorsum of 2 , but not meeting on the median carina ; $3-7$ with a median dorsal triangular spot a little in front of the middle of the segment; 2 and 3 at base and $6-9$ with a lateral spot; no supplementary lateral carinæ; 10 denticulated ventrally.

Appendages brown, leaf-like, a little longer than the

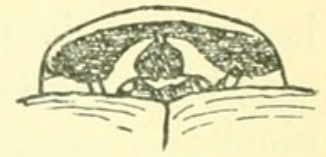

Fig. 13

ESCHNA RILEYI.

Frons and vertex, viewed from above. last two segments; rather narrow, with a slight dorsal longitudinal carina; apices rounded.

Wings hyaline, reticulation dark brown, costa yellowish anteriorly to some distance beyond the nodus. Pterostigma yellow-brown, surmounting 3-3 $\frac{1}{2}$ célls; internal vein prolonged to principal sector. Membranule white, apical third grayish. Subnodal sector with three inferior branchlets (including the terminal one). Upper sector of the arculus arising perceptibly above the middle of the arculus, which latter meets the median vein at the level of the third costal antecubital on the front wings. Two hypertrigonals (three on left hind wing). Triangle of four cells, two on the inner side. Internal triangle present, with one cross vein; four other median cross veins on the front wings, three other on the hind wings, all nearer the base than the arculus. Front wings with $17 \mathrm{R} 16 \mathrm{~L}$ antecubitals, first and seventh thicker; 12 R $11 \mathrm{~L}$ postcubitals, five posttriangular cells, then two rows increasing. Hind wings with 10 antecubitals, first and sixth thicker; 13 R 12 L postcubitals; four posttriangular cells, then three rows increasing.

Locality.-One female in the National Museum collection, from Kilimanjaro. The male is unknown to me.

The coloration of the superior surface of the frons (Fig. 13) is characteristic of this species. I have named it after the late Dr. C. V. Riley, United States Entomologist, to whom I am indebted for the opportunity of studying several collections of Odonata. 


\section{PHAON IRIDIPENNIS, Burmeister.}

Calopteryx iridipennis, Burmeister, Handb. Ent. II, p. 827, 1839.-WALker, List Neur. Ins. Brit. Mus., p. 609, 1853.

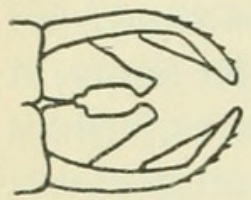

Fig. 14. PHAON IRIDIPEN NIS, male. Dorsal vew of abdom inal appendages. Euphara iridipennis, RambUr, Névr., p. 232, 1842. Phaon iridipennis, Selys, Syn. Calopt., p. 24, 1853; 4e Add., p. 13, 1879; Monog. Calopt., p. 70, pl. 3, figs. 3, 4 (wings), 1854; Enum. Odon. Madag., p. 24, 1869.-Kirbr, Cat. Odon., p. $101,1890$.

One male in the National Museum collection, from Zanzibar, belonging to the typical form, $P$. iridipennis, having a pterostigma.

DISPARONEURA ABBOTTI, new species.

Male.-Black with the following markings:

A yellow band running across the front of the head from eye to eye, just above the epistoma.

Labium and palps yellow, except the tips of the palps which are black.

Anterior, posterior, and lateral margins, a small double spot on the middle of the prothorax, and sometimes one on each side, yellow.

Thorax with a narrow antehumeral stripe, not attaining the antealar sinus, a broad oblique band in which lies the spiracle; all the side posterior to the black stripe which lies upon the whole length of the second lateral suture, and the pectus, greenish.

Coxæ, trochanters, and femora mainly yellowish, the black upon the latter reduced to a superior stripe, which, however, occupies nearly the entire second and third femora at their apices, and nearly all the first femora.

Abdomen: A narrow longitudinal median dorsal stripe on 2, reaching from the base to a little more than half its length; a narrow basal ring on 3-6 interrupted on the median line; apical dorsum of 9 with a triangular spot whose truncated apex, directed forward, is distant from the base of the segment by about one-fourth the segmental length; dorsum of 10 ; inferior lateral margins of $1-8$, confluent with the basal rings on $3-6$, all yellow.

Superior appendages yellow, of the length of the last segment, tapering slightly from base to apex, which latter is slightly thickened internoinferiorly; each appendage apparently bears an intero-inferior basal tooth. Inferior appendages a little longer and darker than the superiors, moderately slender and curved somewhat toward each other in their apical halves.

Wings hyaline, yellowish. Pterostigma black, rhomboidal, surmounting one cell. Median sector arising from the vein of the nodus, the subnodal a short distance after. Lower sector of the triangle arising from the posterior margin of the wing about as far behind the 
postcostal cross vein as the latter is long, and ending near the middle of the cross vein one cell after the vein which terminates the quadrilateral and the space under it. ${ }^{1}$ Sixteen postcubitals on the front wings, thirteen on the hind wings. Superior sector of the triangle ending on the posterior margin at about the sixth cell after the quadrilateral.

Measurements.-Total length, $47 \mathrm{~mm}$. Abdomen, 41. Front wing, 26. Hind wing, 25. Superior appendages, 0.6. Pterostigma, 1.

Locality.-Two males in the National Museum collection, from Kilimanjaro; the last seven abdominal segments of one of them are wanting. The female is unknown to me.

In his "Revision du Synopsis des Agrionines," 2 Baron de Selys arranges the species of Disparoneura in two divisions, of which the first is characterized by the "median sector arising from the vein of the nodus, the subnodal a little after. The rudiment of the lower sector of the triangle parting from the posterior border a little more remote than the basal postcostal nervule and ending at the middle of the vein which terminates the space under the quadrilateral." The second division has the "subnodal sector arising from the vein of the nodus, the median ${ }^{3}$ a little in front of this vein." The first division embraces but one species, D. subnodalis, Selys; the second, twenty-two (including D. delia, Karsch, 1891).

D. abbotti belongs to the first division, whose characters must be modified as follows:

Median sector arising from the vein of the nodus, the subnodal a little after. Lower sector of the triangle arising from the hind margin of the wing farther from the base than the basal postcostal cross vein.

$a$. Lower sector of the triangle ending at the middle of the vein which terminates the space under the quadrilateral................... D. subnodalis, SELYS.

b. Lower sector of the triangle ending near the middle of the vein one cell after that which terminates the space under the quadrilateral...D. abbotti, new species.

D. subnodalis is also described as having a blue band on each side of the head between the epistoma and the eye (apparently not uninterrupted from eye to eye as in abbotti), and on each side of the thorax two small pale juxtahumeral spots placed one above the other (wanting in D. abbotti).

DISPARONEURA MUTATA, Selys (?).

Disparoneura mutata, Selys, Rev. Syn. Agr., p. 164, 1886.-Kirby, Cat. Odon., p. $133,1890$.

Locality.-One male in the National Museum collection, "Taviite, Zanzibar, 'January, 1889."

${ }^{1}$ In the left front wing of one male, the lower sector of the triangle ends at the vein which terminates the space under the quadrilateral.

${ }^{2}$ Mem. Cour. Acad. R. Belg., XXXVIII, 4, 1886, p. 162.

"The original has "sous-nodal" instead of "médian"-an evident misprint. 
I would have no hesitation in referring this male to D. mutata, Selys,

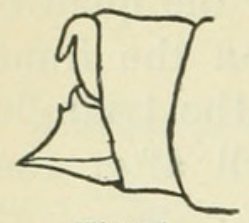

Fig. 15.

DISPARONEURA MU-

TAta (?), Male.

Side view of abdominal ap.

pendages. were it not that his description of the appendages as seen in profile ("de profil on les voit dilatés en dessous en une dent médiane triangulaire") does not mention the two teeth shown in my figure (Fig. 15). The question arises: Can the appendages of the type be partly retracted within the last segment so as to hide the more basal of the two teeth?

\section{AGRION INSULARE, Selys (?).}

Agrion insulare, Selys, Rev. Mag. Zool., p. 179, 1872; Bull. Acad. Belg. (2), XLI, p. $1288,1876$.

Cœnagrion insulare, KIRBY, Cat. Odon., p. 150, 1890.

One male in the National Museum collection, from the Seychelles, collected by Dr. W. L. Abbott, may belong to this species. The last three abdominal segments are wanting. It differs from the description of Baron de Selys ${ }^{1}$ as follows:

Pterostigma covers one and a half cells on front wings, two cells on hind wings; 14-15 postcubitals. No black marks on labrum. A small linear yellow spot each side of vertex. Postocular spots represented by a metallic green patch. All but the head (and wings?) of the type (male) are wanting.

Dorsum of prothorax and thorax metallic green. Prothorax with hind margin rounded, entire. Sides of thorax pale blue (?), a metallic green band on the first lateral suture, a black one on the second lateral suture; both complete.

Feet luteous, with a superior black line.

Dorsum of first three abdominal segments metallic green, of 4-7 black; sides and below, light blue; a basal blue ring on 3-7, interrupted dorsally.

Measurements.-Length of head, thorax, and first 7 abdominal seg. ments, 38 mm. Front wing, 24. Hind wing, 23. Pterostigma, 1.5.

\section{PSEUDAGRION PRÆTEXTATUM, Selys.}

Pseudagrion pratextatum, Selys, Bull. Acad. Belg. (2), XLIII, p. 494, 1876.Kirby, Cat. Odon., p. 153, 1890.

Thirteen males and six females in the National Museum eollection, from Kilimanjaro, belong apparently to this species. Only one male has the abdomen complete, and its appendages are in such bad condition as to afford no help in identification. The colors of these specimens agree with the description. The younger males have the sides of the thorax pale green, a short black stripe at the base of the front wings, no black marks on the pectus, the abdomen with a greenish metallic or bluish metallic luster. 


\section{$2 \mathrm{BHL}$ Biodiversity Heritage Library}

Calvert, Philip Powell. 1896. "East African Odonata, collected by Doctor W. L. Abbott." Proceedings of the United States National Museum 18(1046), 121-142. https://doi.org/10.5479/si.00963801.18-1046.121.

View This Item Online: https://www.biodiversitylibrary.org/item/32799

DOI: https://doi.org/10.5479/si.00963801.18-1046.121

Permalink: https://www.biodiversitylibrary.org/partpdf/5692

\section{Holding Institution}

Smithsonian Libraries

\section{Sponsored by}

Smithsonian

\section{Copyright \& Reuse}

Copyright Status: NOT_IN_COPYRIGHT

This document was created from content at the Biodiversity Heritage Library, the world's largest open access digital library for biodiversity literature and archives. Visit BHL at https://www.biodiversitylibrary.org. 